\title{
CULTURAL INDUSTRIES AND THEIR RELATIONSHIPS WITH PRESERVING THE IDENTITY
}

Ghada Majid Muhammad JALALI*

Faculty of Applied Arts, Helwan University, Egypt

\begin{abstract}
Preserving the cultural identity depends to a large extent on the cultural and creative industries through which it appears the cultures of different societies, the cultural and creative industries embody forms of cultural expressions, regardless of its commercial value is included in the cultural industries (handicrafts), as it is not a cultural industry in its own right, The precise concept has expanded to include industries (creativity), which in turn preserve the cultural identity of societies.

Keywords

Cultural Industries, Preservation, The Identity, Heritage.
\end{abstract}

The role of women in crafts and environmental industries:

A woman, as a mother and a housewife, can practice the craft in

Times that suit her and in places she chooses Or even at her home with lower costs For training, as it is mainly based on the training method While working as well as using it mostly For simple, uncomplicated techniques.

\section{The historical importance of the handicraft industries:}

The handicraft industries have their historical, cultural and social importance as well as the foundation Economically, from the social point of view, handicraft industries can be considered a small industry Therefore, it helps to reduce unemployment by taking advantage of young people (males and females) and doing business Sometimes in homes, as well as the elderly and those with special needs, this of course gives a financial boost in addition to raising the morale in front of the historical point of view, history is full of names of industries and manufacturers .It is now considered the best way to express the country's national identity and one of the most important means of preserving heritage Due to the invasion of modern industry, the traditional industries have receded.

Traditional industries and crafts and their importance for the economy of the Arab world:

Traditional industries and crafts are important in different countries of the world and for different peoples the governments of these countries attach great importance to these industries Although some of these countries are major industrialized countries and have giant modern industries, however, it finds in the traditional industries an economic and social importance.

*Corresponding author: appliedarts@a-arts.helwan.edu.eg 
The importance of these traditional industries in our Arab world stems from the fact that they contribute to the growth of the GDP

The total amount, and create job opportunities for a large segment of the citizens of those countries, and sources of national income and individual, and you find a great turnout from different segments of society, especially since there are secrets that live on those Traditional industries, professions and crafts.

The role that industries play in encouraging citizens to settle in the places they belong to: These industries could constitute a qualitative addition in the framework of planning to expand the production base In the national economy, and contribute to absorbing shocks that may be exposed to the economy during the course of the year In the coming years, and enable it to face future internal and external challenges.

These industries, if established in remote areas and villages, could encourage citizens to: Stability in their areas without having to migrate to cities, and from here the pressure can be relieved Population as well as traffic to cities in the country, especially after this population pressure has come to light Significant repercussions and impacts on society The interest in these industries stems from the importance of localizing the national economy in terms of employment National capital and human citizenship capacity in order to activate the various sectors Economic, especially the private sector, so that the economy becomes a de facto national identity.

The interest in these industries comes in line with recent trends in adopting small projects The development of these industries enhances the path towards the success of private enterprises and the encouragement of young people Investors, so that these projects contribute to achieving a national economic base.

We find that The traditional manufacturer, whether an individual or a simple contractor, resort to different strategies to meet the working condition Manual ones:

\section{Dependence on the family workforce:}

The handicrafts and traditional industries, both ancient and modern, occupy a large area of the original heritage.

It is considered a torch for its beacon in the Empty Ages and a symptom of its civilization among nations. And it continued Crafts and industries are evident even in our present time, and enjoy the traditional industries and handicrafts Handmade has a wide reputation in the Arab world, where it was able to compete with others Items and handicrafts. 


\section{Traditional Industries Authenticity Code:}

Despite the development and progress achieved by the Arab world in all aspects of life, the preservation of heritage Al-Asil was a fundamental pillar of the modern state and an epic of the glorious features of society, considering that Heritage is an essential element in the formation of the national identity, and the interest in heritage has extended to the care of the letter

And traditional patriotism, despite the tremendous development in the tools and means of production. Documenting handicrafts to preserve the identity of societies:

The process of registering and documenting handicraft industries in all regions of the Arab world is a necessary step

To preserve these industries and to take care of their workers, which formed an important pillar for the development of a strategy To promote the traditional crafts and handicraft industries, especially as they have become one of the elements

Tourist attraction by contributing to many exhibitions.

\section{Some models of traditional crafts:}

\section{Texture:}

The textile industry was known from ancient times, and this industry was known to the Assyut people in making Sadu by spinning sheep or goat wool, the Bedouin was able to weave wool Poetry is to build its dwelling place with it, and the women of Upper Egypt were also famous for making a ruble from sheep's wool as well as I worked on weaving the adultery of beauty by means of spinners, which are the purpose, the baddad, the seih and the khatt And the tightening and the comprehensive and the one and the two Assiut was famous for its manufacture of buttons and turbans.

\section{Jewelry and silverware:}

As for the one who makes jewelry, he is known as jewelers, which is one of the profitable industries Good economic, and the Al-Hussein region is considered one of the most important centers of jewelers industry, like other regions Similar in the countries of the Arab world, and jewelry makers and silver makers are especially famous for their engravings for flowers.

\section{Challenges facing the heritage of the Arab world:}

There are also risks that constitute a threat to the intangible heritage, thereby reducing it, changing it, or It distorts it, and may end its survival, perhaps the most important of which is globalization and the steady development of economic life And social. Globalization represents the great challenge to the heritage, cultural peculiarities, and even constants the civilization of the nation, such as: religion, language, history, customs, traditions, and customs. Its effects are 
Negativity in spreading ideas and behaviors that would tear loyalty to heritage values and disconnect generations the new nation has its past and legacy, and the replacement of new ideas and loyalties alien to the Ummah. The result is a bulge the phenomenon of cultural dependency and the separation of peoples from their identity and privacy.

\section{Methods of preservation heritage in its various forms:}

Aware of the importance and value of this heritage, awareness of the seriousness of the threats that it is exposed to, and in the face of what It is exposed to challenges that threaten its survival, the preservation of which was the imperative. And as you agree The threats and the nature of the heritage, the strategies of preservation also are consistent with the nature or quality of this heritage, The preservation of tangible heritage takes many forms, including: restoration, treatment, preservation and preservation, Protection, maintenance, re-installation or rebuilding and retrofitting. The efforts of many sciences are combined, each In his specialization, and contribute a large share to preserving the heritage, including sciences; Chemistry, Physics, geology, biology, architecture and more.

\section{Procedures that must be in place to preserve the Arab heritage:}

Caring for, caring for and preserving intangible heritage was a national duty and necessity Scientific as it represents a field in which a group of social sciences meet. Include Methodology for preserving the intangible cultural heritage, or folklore, and folklore materials; a set of procedures includes collecting and documenting heritage materials, whether it is a collection In the field, or a collection of blogs and books, then the classification into the recognized sections, which are? Customs and traditions, folk literature, popular beliefs and knowledge, and various popular arts Whether it is expressive arts, performing arts or plastic crafts.

\section{References}

1- Bayoumi Al-Shimi: a comparative study of some international experiences in developing and developing projects

Small and medium,. 2008

2- Dr. Nabil Ali's book: Arab culture and the information age, an Arab vision for the future of Arab culture and the information age.

3- http://www.al-jazirah.com/2015/20151108/wo2.htm

4-http://www.alyaum.com/article/2496097

5-http://www.alyaum.com/article/102615

Received: February 15, 2018

Accepted: April 20, 2018 